\title{
NOTE
}

\section{Cosmetic Substance Synthesis from Estragole Derivatives for Skin Depigmentation}

\author{
Masato Nomura ${ }^{* 1}$, Yutaka MotokI ${ }^{* 1}$, Yoshihito FuJIHARA ${ }^{* 1}$, \\ Takahiro TADA ${ }^{* 2}$ and Kenji SHImomurA ${ }^{* 2}$ \\ * 1 Department of Chemistry and Environmental Technology, Faculty of Engineering, Kinki University \\ (Umenobe, Takaya, Higashihiroshima 739-2116, JAPAN) \\ * 2 Natural Material Group, Reseach \& Development Division, Mikimoto Pharmaceutical Co., Ltd. \\ (Kurose, Ise, Mie 516-0018, JAPAN)
}

Edited by Y. Hirose, Yamanashi Univ., and accepted September 3, 2001 (received for review January 19, 2001)

\begin{abstract}
Natural material extracts are presently used as cosmetic ingredients. Their physiological effects were examined using estragole isolated from the essential oil of Foeniculum vulgare Miller as starting materials. Thirty derivatives were synthesized by condensation using ten thiols. The derivatives were examined for potential use as whitening agents possessing tyrosinase activity and superoxide dismutase. Derivative compounds were found good inhibitors of tyrosinase.
\end{abstract}

J. Oleo Sci., 51, 57-62 (2002).

Key words: Foeniculum vulgare Miller, estragole, whitening effect, tyrosinase, primary irritation test

\section{Introduction}

In recent years, it is feared that the stratospheric ozone layer depletion by chlorofluorocarbons released into the atmosphere. They are only released into the atmosphere might adversely affect animals, humans and plants. It is said that a $1 \%$ depletion of the ozone layer causes about a $2 \%$ increase in the ultraviolet rays of 280 to $320 \mathrm{~nm}$ in wavelength (i.e., so-called UV-B rays harmful to living organisms). Since many biological substances such as genes and plant hormones have absorption peaks in the UV region, effects of the increase in UV-B rays on ecological systems have attracted public attention as a serious problem (1). As one of these effects, tyrosinase in the skin is activated and thus causes melanogenesis, there by inducing pigmentation. It has been found that this phenomenon can be prevented by plant components such as arbutin, ellagic acid and recinol (2). On the other hand, we paid

Corresponding author: Masato NOMURA our attention to the pharmacological activities of anethole and estragole, which are essential oil components of Foeniculum vulgare Miller, a chinese herbal drug, and found out that derivatives of these substances obtained via various reactions show remarkable effects of inhibiting tyrosinase activity (3). These results have been already reported. In this study, which relates to the above findings, we attempted to synthesize a compound having a high whitening effect by preparing estragole derivatives having an $\mathrm{S}$ atom in the side chain. The compound thus obtained was subjected to a tyrosinase activity inhibition test and those showing high inhibitory activities were further subjected to a skin primary irritation test. As a result, a favorable compound could be obtained, as will be reported hereinafter. For comparison, $p$-anisic acid and 4-methoxyphenylacetic acid, each having a similar mother nuclear structure, were subjected to the same reactions as in the case of estragole. The compounds thus obtained were examined for whitening effects and thus the difference in the effects was clarified. 


\section{Experimental}

\section{$2 \cdot 1$ Materials}

The starting material, estragole (1) was obtained from KANTO CHEMICAL CO., INC..

(1): bp $.215-216^{\circ} \mathrm{C}, \mathrm{d}_{4}^{20}=0.9658$.

\section{$\mathbf{2} \cdot \mathbf{2}$ Analysis}

The structures of the compounds were determined by IR spectra (JASCO IR-810), ${ }^{1} \mathrm{H}-\mathrm{NMR}$ spectra (JEOL JNM-EX400) and GC-MS data (JEOL JMS-HX100).

\section{$2 \cdot 3$ Synthesis}

\section{$2 \cdot 3 \cdot 1$ 3-(4-Methoxyphenyl)-1-propanal (2) (4)}

Added $0.13 \mathrm{~g}\left(3.4 \times 10^{-3} \mathrm{~mol}\right)$ of $\mathrm{NaBH}_{4}$ and $5 \mathrm{ml}$ of THF to a $50 \mathrm{~mL}$ three-neck flask and refluxed. A solution $0.50 \mathrm{~g}\left(3.4 \times 10^{-3} \mathrm{~mol}\right)$ of (1) dissolved in $2 \mathrm{~mL}$ of distilled THF was added, $\mathrm{BF}_{3} \cdot \mathrm{Et}_{2} \mathrm{O} \quad 0.68 \mathrm{~g}\left(4.8 \times 10^{-3}\right.$ mol) was dropped slowly and stirred for $2 \mathrm{~h}$ at $50^{\circ} \mathrm{C}$ on an oil bath. Added $2.5 \mathrm{~mL}$ water, $2.5 \mathrm{~mL} 3 \mathrm{M}$ $\mathrm{NaOH}$ (aq.) $\left(1 \mathrm{M}=1 \mathrm{~mol} \mathrm{dm}^{-3}\right)$, and $2.5 \mathrm{~mL} \mathrm{H}_{2} \mathrm{O}_{2}$ slowly and stirred for $12 \mathrm{~h}$. The mixture was extracted with ether, washed with saturated $\mathrm{NaCl}$ (aq.), dried over anhydrous $\mathrm{Na}_{2} \mathrm{SO}_{4}$ and evaporated. The residue was chromatographed on silica gel (hexane : ethyl acetate $=$ $6: 4)$ to give (2) $(0.30 \mathrm{~g}, 53.6 \%$ yield).

(2): IR $v \max \left(\mathrm{cm}^{-1}\right) ; 3400(-\mathrm{OH}), 2950\left(-\mathrm{OCH}_{3}\right)$, $1510,1610(\phi) .{ }^{1} \mathrm{H}-\mathrm{NMR} \delta \mathrm{CDCl}_{3}(\mathrm{ppm}) ; 1.80(2 \mathrm{H}$, m, $\left.-\mathrm{CH}_{2} \mathrm{CH}_{2} \mathrm{CH}_{2} \mathrm{OH}\right), 2.59\left(2 \mathrm{H}, \mathrm{t}(\mathrm{J}=7.2 \mathrm{~Hz}),-\mathrm{CH}_{2} \mathrm{CH}_{2}\right.$ $\left.\mathrm{CH}_{2} \mathrm{OH}\right), 3.58\left(2 \mathrm{H}, \mathrm{t}(\mathrm{J}=7.2 \mathrm{~Hz}),-\mathrm{CH}_{2} \mathrm{CH}_{2} \mathrm{CH}_{2} \mathrm{OH}\right)$, $3.70\left(3 \mathrm{H}, \mathrm{s},-\mathrm{OCH}_{3}\right), 6.77 \sim 7.07(4 \mathrm{H}, \mathrm{m}, \phi)$.

\section{$2 \cdot 3 \cdot 2$ 3-(4-Methoxyphenyl) propanal (3)}

Added pyridinium dichromate $13.6 \mathrm{~g}\left(3.6 \times 10^{-2} \mathrm{~mol}\right)$ to a $500 \mathrm{~mL}$ four-neck flask and added $\mathrm{CH}_{2} \mathrm{Cl}_{2}$ and 4.0 $\mathrm{g}\left(2.4 \times 10^{-2} \mathrm{~mol}\right)$ of $(2)$ then stirred for $1 \mathrm{~h}$ at $0^{\circ} \mathrm{C}$ on an ice bath. Stirred for $24 \mathrm{~h}$ at room temperature. Removed chrome by silica gel column chromatography (ethyl acetate only) and evaporated. The residue was acidified by $10 \% \mathrm{HCl}$ (aq.), washed with saturated $\mathrm{NaCl}$ (aq.), dried over anhydrous $\mathrm{Na}_{2} \mathrm{SO}_{4}$ and evaporated. The residue was purified by chromatography using silica gel ( hexane : ethyl acetate $=9: 1$ ) to give (3) (2.9g, 72.5\% yield).

(3): IR $v \max \left(\mathrm{cm}^{-1}\right) ; 2950\left(-\mathrm{OCH}_{3}\right), 1730(-\mathrm{CHO})$, $1510,1610(\phi) .{ }^{1} \mathrm{H}-\mathrm{NMR} \delta \mathrm{CDCl}_{3}(\mathrm{ppm}) ; 2.84(2 \mathrm{H}, \mathrm{t}$ $\left.(\mathrm{J}=7.2 \mathrm{~Hz}),-\mathrm{CH}_{2} \mathrm{CH}_{2} \mathrm{CHO}\right), 3.01(2 \mathrm{H}, \mathrm{t}(\mathrm{J}=7.2 \mathrm{~Hz})$, $\left.-\mathrm{CH}_{2} \mathrm{CH}_{2} \mathrm{CHO}\right), 3.88\left(3 \mathrm{H}, \mathrm{s},-\mathrm{OCH}_{3}\right), 6.95 \sim 7.24(4 \mathrm{H}$, m, $\phi), 9.89$ (1H, s, -CHO).

\section{$2 \cdot 3 \cdot 3$ 3-(4-Methoxyphenyl) propionirile (4)}

Added (3) $\left(1.8 \times 10^{-2} \mathrm{~mol}\right), \mathrm{N}, \mathrm{N}$-dimethylhydradine $1.6 \mathrm{~g}\left(2.7 \times 10^{-2} \mathrm{~mol}\right)$ and dry benzene into a $300 \mathrm{~mL}$ four-neck flask and refluxed for $3 \mathrm{~h}$ at $75 \sim 85^{\circ} \mathrm{C}$. Then azeotroped water and benzene at $120^{\circ} \mathrm{C}$ and stirred for 3 $\mathrm{h}$ at $0^{\circ} \mathrm{C}$. Added $\mathrm{CH}_{3} \mathrm{I}\left(4.4 \mathrm{~g}, 3.1 \times 10^{-2} \mathrm{~mol}\right)$ was added then stirred for $1 \mathrm{~h}$ at the same temperature and refluxed for $4 \mathrm{~h}$ at $70 \sim 80^{\circ} \mathrm{C}$. Filtrated hydrazinium salt with ether was added to $1 \mathrm{M}-\mathrm{KOH}-\mathrm{MeOH}(\mathrm{aq}$.$) , then$ refluxed for $10 \mathrm{~h}$ at $60 \sim 70^{\circ} \mathrm{C}$. The mixture was extracted with ether, washed with saturated $\mathrm{NaCl}$ (aq.), dried over anhydrous $\mathrm{Na}_{2} \mathrm{SO}_{4}$ and evaporated. The residue was chromatographed on silica gel ( hexane : ethyl acetate $=9: 1)$ to give (4) $(1.5 \mathrm{~g}, 50.0 \%$ yield $)$.

(4): IR $v \max \left(\mathrm{cm}^{-1}\right) ; 2225(-\mathrm{CN}), 2950\left(-\mathrm{OCH}_{3}\right)$, $1510,1610(\phi) .{ }^{1} \mathrm{H}-\mathrm{NMR} \delta \mathrm{CDCl}_{3}(\mathrm{ppm}) ; 2.54(2 \mathrm{H}, \mathrm{t}$ $\left.(\mathrm{J}=7.3 \mathrm{~Hz}),-\mathrm{CH}_{2} \mathrm{CH}_{2} \mathrm{CN}\right), 2.86(2 \mathrm{H}, \mathrm{t}(\mathrm{J}=7.3 \mathrm{~Hz})$, $\left.-\mathrm{CH}_{2} \mathrm{CH}_{2} \mathrm{CN}\right), 3.76\left(3 \mathrm{H}, \mathrm{s},-\mathrm{OCH}_{3}\right), 6.83 \sim 7.14(4 \mathrm{H}, \mathrm{m}$, $\phi)$.

\section{$2 \cdot 3 \cdot 4$ 3-(4-Methoxyphenyl) propanoic acid (5C)}

Added (4) $\left(9.3 \times 10^{-3} \mathrm{~mol}\right)$ and $1 \mathrm{M}-\mathrm{KOH}-\mathrm{MeOH}(\mathrm{aq}$. to a $300 \mathrm{~mL}$ four-neck flask and refluxed for $48 \mathrm{~h}$ at $60 \sim 70^{\circ} \mathrm{C}$. Evaporated $\mathrm{MeOH}$ and the residue were extracted with saturated $\mathrm{NaCl}$ (aq.), dried over anhydrous $\mathrm{Na}_{2} \mathrm{SO}_{4}$, and evaporated. The residue was chromatographed on silica gel ( hexane-ethyl acetate $=3: 7$ ) to give (5C) (1.1g, 68.8\% yield).

(5C): IR $v \max \left(\mathrm{cm}^{-1}\right) ; 2850\left(-\mathrm{OCH}_{3}\right), 1700(-\mathrm{COOH})$, $1420,1620(\phi) .{ }^{1} \mathrm{H}-\mathrm{NMR} \delta \mathrm{CD}_{3} \mathrm{OD}(\mathrm{ppm}) ; 2.06(2 \mathrm{H}, \mathrm{t}$ $\left.(\mathrm{J}=7.6 \mathrm{~Hz}),-\mathrm{CH}_{2} \mathrm{CH}_{2} \mathrm{COOH}\right), 2.57(2 \mathrm{H}, \mathrm{t}(\mathrm{J}=7.2 \mathrm{~Hz})$, $\left.-\mathrm{CH}_{2} \mathrm{CH}_{2} \mathrm{COOH}\right), 3.75\left(3 \mathrm{H}, \mathrm{s},-\mathrm{OCH}_{3}\right), 6.74 \sim 7.09(4 \mathrm{H}$, $\mathrm{m}, \phi)$.

\section{$2 \cdot 3 \cdot 5$ Condensation reaction $(\mathbf{5 A}-\mathbf{a}) \sim(\mathbf{5 C}-\mathbf{j})$}

Dissolved (5C) $\left(1.0 \mathrm{~g}, 6.4 \times 10^{-3} \mathrm{~mol}\right)$ in ethanethiol $0.4 \mathrm{~g}\left(6.4 \times 10^{-3} \mathrm{~mol}\right)$, diethyl cyanophosphonate $(0.9 \mathrm{~g}$, $\left.5.5 \times 10^{-3} \mathrm{~mol}\right)$ and $\mathrm{Et}_{3} \mathrm{~N}\left(0.6 \mathrm{~g}, 5.9 \times 10^{-3} \mathrm{~mol}\right)$ under a nitrogen atmosphere at $0^{\circ} \mathrm{C}$, and then stirred for $24 \mathrm{~h}$ at room temperature. The residue was extracted with ether, washed with saturated $\mathrm{NaCl}$ (aq.), dried over anhydrous $\mathrm{Na}_{2} \mathrm{SO}_{4}$ and evaporated. The residue was chromatographed on silica gel ( hexane-ether $=9: 1$ ), then deodorized by activated carbon to give (5C-a) $(0.9 \mathrm{~g}, 72.0 \%$ yield $)$. By using the same method, condensed (5A-a) (5C-j) ( 0.4 1.4 g, 40.6 96.2\% yield). Physical constants and yields are shown in Table 1.

(5C-a): ${ }^{1} \mathrm{H}-\mathrm{NMR} \delta \mathrm{CDCl}_{3}(\mathrm{ppm}) ; 1.19(3 \mathrm{H}, \mathrm{t}(\mathrm{J}=7.6$ $\left.\mathrm{Hz}),-\mathrm{CH}_{2} \mathrm{CH}_{3}\right), 2.76\left(2 \mathrm{H}, \mathrm{m}, \phi-\mathrm{CH}_{2} \mathrm{CH}_{2}-\right)$, $2.82\left(2 \mathrm{H}, \mathrm{q}(\mathrm{J}=7.6 \mathrm{~Hz}),-\mathrm{CH}_{2} \mathrm{CH}_{3}\right), 2.87(2 \mathrm{H}$, 
m, $\left.\phi-\mathrm{CH}_{2} \mathrm{CH}_{2}-\right), 3.69\left(3 \mathrm{H}, \mathrm{s},-\mathrm{OCH}_{3}\right)$, 6.76 7.06 (4H, m, $\phi)$.

MS m/z (rel.int \%); $224\left(\mathrm{M}^{+}, 40\right), 134$ (45), 121 (100), 105 (4), 91 (8), 77 (6).

(5C-b): 'H-NMR $\delta \mathrm{CDCl}_{3}(\mathrm{ppm}) ; 0.89(3 \mathrm{H}, \mathrm{t}(\mathrm{J}=7.2$ $\left.\mathrm{Hz}),-\mathrm{CH}_{2} \mathrm{CH}_{3}\right), 1.52(2 \mathrm{H}$, sex $(\mathrm{J}=7.2 \mathrm{~Hz})$, $\left.-\mathrm{CH}_{2} \mathrm{CH}_{3}\right), 2.74\left(2 \mathrm{H}, \mathrm{m}, \phi-\mathrm{CH}_{2} \mathrm{CH}_{2^{-}}\right), 2.78$ $\left(2 \mathrm{H}, \mathrm{t}(\mathrm{J}=7.2 \mathrm{~Hz}),-\mathrm{CH}_{2} \mathrm{CH}_{2} \mathrm{CH}_{3}\right), 2.85(2 \mathrm{H}$, $\left.\mathrm{m}, \phi-\mathrm{CH}_{2} \mathrm{CH}_{2}-\right), 3.65\left(3 \mathrm{H}, \mathrm{s},-\mathrm{OCH}_{3}\right)$, $6.73 \sim 7.04(4 \mathrm{H}, \mathrm{m}, \phi)$.

MS m/z (rel.int \%); $238\left(\mathrm{M}^{+}, 35\right), 134(51)$, 121 (100), 105 (3), 91 (7), 77 (5).

(5C-c): ${ }^{1} \mathrm{H}-\mathrm{NMR} \delta \mathrm{CDCl}_{3}(\mathrm{ppm}) ; 0.88(3 \mathrm{H}, \mathrm{t}(\mathrm{J}=7.2$ $\left.\mathrm{Hz}),-\mathrm{CH}_{2} \mathrm{CH}_{3}\right), 1.32(2 \mathrm{H}$, sex $(\mathrm{J}=7.2 \mathrm{~Hz})$, $\left.-\mathrm{CH}_{2} \mathrm{CH}_{3}\right), 1.49(2 \mathrm{H}$, qui $(\mathrm{J}=7.2 \mathrm{~Hz})$, $\left.-\mathrm{SCH}_{2} \mathrm{CH}_{2}-\right), 2.76\left(2 \mathrm{H}, \mathrm{m}, \phi-\mathrm{CH}_{2} \mathrm{CH}_{2}-\right), 2.83$ $\left(2 \mathrm{H}, \mathrm{t}(\mathrm{J}=7.2 \mathrm{~Hz}),-\mathrm{SCH}_{2}-\right), 2.87(2 \mathrm{H}, \mathrm{m}, \phi-$ $\left.\mathrm{CH}_{2} \mathrm{CH}_{2}-\right), 3.68\left(3 \mathrm{H}, \mathrm{s},-\mathrm{OCH}_{3}\right), 6.75 \sim 7.06$ $(4 \mathrm{H}, \mathrm{m}, \phi)$.

MS m/z (rel.int\%); $252\left(\mathrm{M}^{+}, 32\right), 134$ (57), 121 (100), 105 (3), 91 (6), 77 (5).

(5C-d): ${ }^{1} \mathrm{H}-\mathrm{NMR} \delta \mathrm{CDCl}_{3}(\mathrm{ppm}) ; 2.73(2 \mathrm{H}, \mathrm{m}, \phi$ $\left.\mathrm{CH}_{2} \mathrm{CH}_{2}-\right), 2.87\left(2 \mathrm{H}, \mathrm{m}, \phi-\mathrm{CH}_{2} \mathrm{CH}_{2^{-}}\right), 2.96$ $(1 \mathrm{H}, \operatorname{sep}(\mathrm{J}=7.2 \mathrm{~Hz}),-\mathrm{SCH}-), 3.21(3 \mathrm{H} \times 2, \mathrm{~d}$ $(\mathrm{J}=7.2 \mathrm{~Hz})$, gem- $\left.\mathrm{CH}_{3}\right), 3.69\left(3 \mathrm{H}, \mathrm{s},-\mathrm{OCH}_{3}\right)$, 6.76 7.06 (4H, m, $\phi)$.

MS m/z (rel.int \%); $238\left(\mathrm{M}^{+}, 25\right), 134$ (58), 121 (100), $105(3), 91(6), 77$ (5).

\subsection{Assay}

$2 \cdot 4 \cdot 1$ in vitro $(5)$

Inhibition of tyrosinase activity. Tyrosinase activity was determined by the dopachrome method with L-tyrosine or L-DOPA as substrate.

a) With the L-tyrosine substrate: The reaction mixture $(2 \mathrm{~mL})$ which contained $1.66 \mathrm{mM}$ L-tyrosine, 10.0 $\mathrm{mM}$ phosphate buffer ( $\mathrm{pH} \mathrm{6.8),} 30$ units of mushroom tyrosinase [Shigma Chemical Co. (EC 1.14.18.1)] and the sample (a $1.66 \mathrm{mM}$ DMSO solution; $1.0 \mathrm{~mL}$ ) was incubated at $37^{\circ} \mathrm{C}$ for 10 min. Absorbance was then measured at $475 \mathrm{~nm}$. A control reaction was carried out without the sample.

Percent inhibition of tyrosinase was calculated as follows:

Tyrosinase inhibition $(\%)=\left\{\left(T_{2}-\left(T_{1}-T_{3}\right)\right) / T_{2} \times 100\right\}$ $T_{1}$ and $T_{2}$ represent the absorbance of the test solution and simultaneous control, respectively; $T_{3}$ represents absorbance of the sample itself.

b) With the L-DOPA substrate: The reaction mixture (3 mL) which contained $1.66 \mathrm{mM} \mathrm{L}$-DOPA, 19.0 $\mathrm{mM}$ phosphate buffer ( $\mathrm{pH} \mathrm{6.8)}, 30$ units mushroom tyrosinase and the sample (a $1.66 \mathrm{mM}$ DMSO solution; $1.0 \mathrm{~mL}$ ) was incubated at $25^{\circ} \mathrm{C}$ for 1.75-2.75 min. The control reaction was carried out without the test sample. Absorbance was measured at $475 \mathrm{~nm}$ before and after incubation. Percent inhibition of tyrosinase was calculated as follows:

Tyrosinase inhibition $(\%)=\left(T_{1}-T_{2}\right) / T_{1} \times 100$

$T_{1}$ represents the difference in absorbance of the control before and after incubation, and $T_{2}$ is the difference in absorbance of the test solution before and after incubation.

Superoxide dismutase. The reaction mixture $(30 \mathrm{~mL})$ which contained the sample (a $0.3 \mathrm{mM}$ DMSO solution; $0.1 \mathrm{~mL}$ ), xantin , hydroxylamine hydrochloride, $\mathrm{N}-1$ naftyletylenediamine dihydrochloride and xantinoxidase, was incubated at $37^{\circ} \mathrm{C}$ for $20 \mathrm{~min}$. Sodium dodecyl sulfate was then added to the mixture, and the absorbance was measured at $560 \mathrm{~nm}$.

Superoxide Dismutase $(\%)=\left(T_{1}-T_{2}\right) / T_{1} \times 100$ $T_{1}$ represents the absorbance of the control after incubation, and $T_{2}$, absorbance of the test solution after incubation.

\section{$2 \cdot 4 \cdot 2$ in vivo}

Primary irritation test using a guinea pig. The hair was removed from both abdomens of the guinea pig and the test body was smeared with a prepared fixed concentration $(0.1 \%$ sample + squalane, $1.0 \%$ sample + squalane, $5.0 \%$ sample + squalane and squalane only). Patch bonds were fixed on one side of each of two test bodies, a part in right front in turn. Affixing was carried out by the circuit method and fixed by tape. After $24 \mathrm{~h}$, patch bonds were removed, and erythema and edema of the part of fixing test body were estimated by removing patch bonds after $1 \mathrm{~h}, 24 \mathrm{~h} 48 \mathrm{~h}$ and $72 \mathrm{~h}$. The results are shown in Table 3 (Draize method) (6). The Stimulus index was calculated as follows:

Stimulus index $=($ each erythema score + each edema score) / the number of animals

Absolute estimation score: Adopted higher score of stimulus index after $1 \mathrm{~h}$ and $24 \mathrm{~h}$. Stimulus estimation data are as follows: 


\begin{tabular}{c|l}
\hline Absolute estimation score & \multicolumn{1}{c}{ estimation } \\
\hline $0.00 \sim 0.20$ & non - stimulus \\
\hline $0.21 \sim 0.50$ & weak - stimulus \\
\hline $0.51 \sim 1.00$ & middle - stimulus \\
\hline $1.01 \sim 1.50$ & middle - strong - stimulus \\
\hline $1.50 \sim$ & strong - stimulus \\
\hline
\end{tabular}

The absolute estimation score was less than 1.00 , which is suitable, and more than 1.51 , which is not suitable as a cosmetic ingredient.

\section{Results and Discussion}

Thirty products were examined for tyrosinase inhibi-

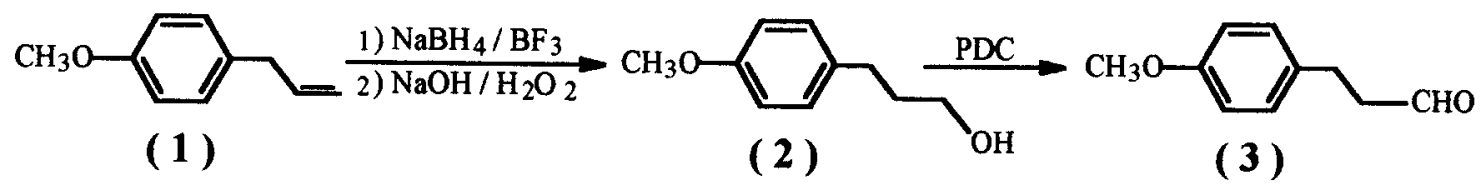

1) $\left(\mathrm{CH}_{3}\right)_{2} \mathrm{NNH}_{2}$

2) Mel / Dry - benzene

3) $\mathrm{KOH} / \mathrm{MeOH}$

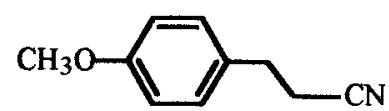

(4)

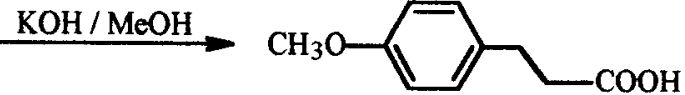

(5C)

Fig. 1 Synthesis Procedure from (1) (5C).

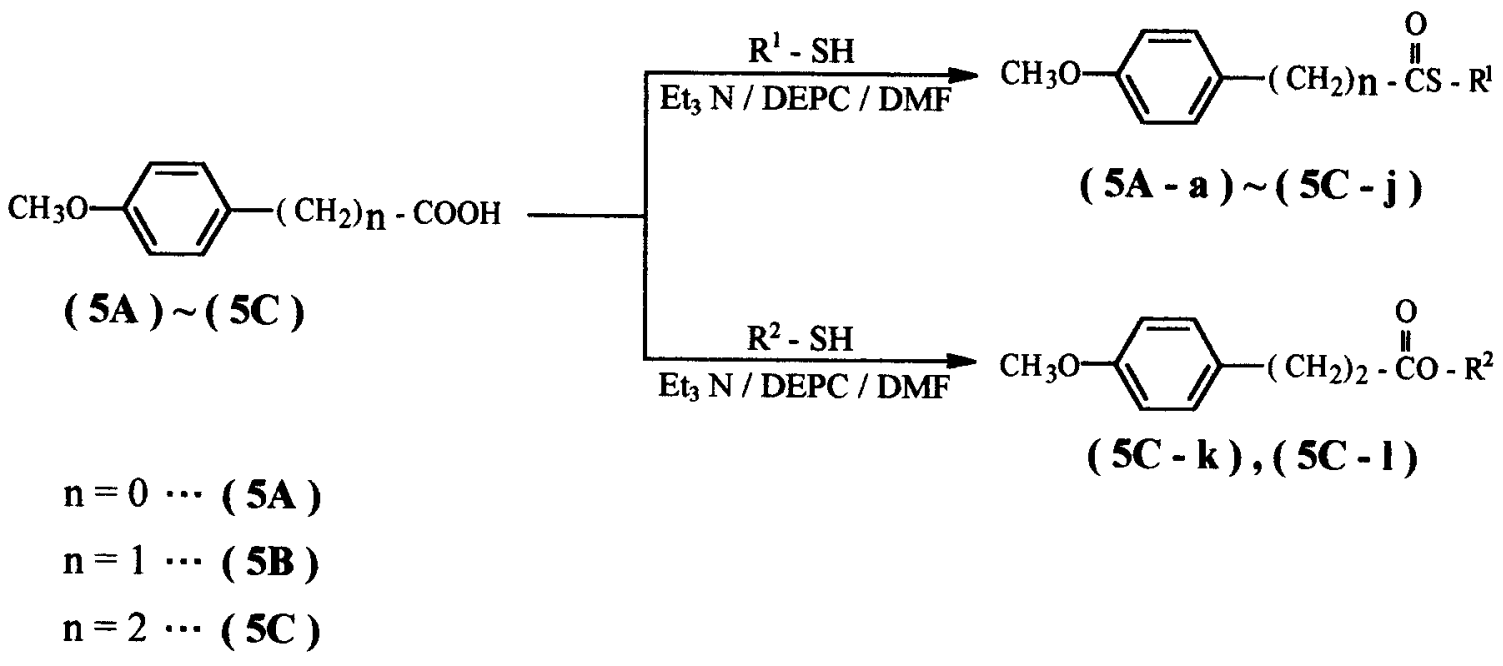

$$
\begin{aligned}
\mathrm{R}^{1} & =\left[\begin{array}{llll}
\mathrm{CH}_{3} \mathrm{CH}_{2-*} & \cdots \text { (a) } & \left(\mathrm{CH}_{3}\right) \mathrm{CHCH}_{2-*} & \cdots \text { (f) } \\
\mathrm{CH}_{3}\left(\mathrm{CH}_{2}\right)_{2-*} & \cdots \text { (b) } & \mathrm{CH}_{3} \mathrm{OCOCH}_{2}-* & \cdots(\mathrm{g}) \\
\mathrm{CH}_{3}\left(\mathrm{CH}_{2}\right)_{3-*} & \cdots \text { (c) } & \mathrm{CH}_{3} \mathrm{CH}_{2} \mathrm{OCOCH}_{2-*} & \cdots \text { ( ( ) } \\
\left(\mathrm{CH}_{3}\right)_{2} \mathrm{CH}-* & \cdots \text { (d) } & \mathrm{CH}_{3} \mathrm{OCO}\left(\mathrm{CH}_{2}\right)_{2-*} & \cdots(\mathrm{i}) \\
\mathrm{CH}_{3} \mathrm{CH}_{2}\left(\mathrm{CH}_{3}\right) \mathrm{CH}-* & \cdots \text { (e) } & \mathrm{CH}_{3} \mathrm{CH}_{2} \mathrm{OCO}\left(\mathrm{CH}_{2}\right)_{2} * & \cdots(\mathrm{j})
\end{array}\right. \\
\mathrm{R}^{2} & =\left[\begin{array}{lll}
\mathrm{CH}_{3}\left(\mathrm{CH}_{2}\right)_{2-*} & \cdots \text { (k) } \\
\mathrm{CH}_{3}\left(\mathrm{CH}_{2}\right)_{3-*} & \cdots \text { (1) }
\end{array}\right.
\end{aligned}
$$

Fig. 2 Synthesis Procedure from (5A-a) $(5 C-1)$. 
Table 1 Physical Constants and Yields of (5A-a) (5C-d).

\begin{tabular}{c|ccc}
\hline Compound & $\mathrm{n}_{\mathrm{D}}^{20}$ a) & $\mathrm{d}_{4}^{20}$ b? & Yield $(\%)$ \\
\hline $\mathbf{( 5 A}-\mathbf{a})$ & 1.5820 & 1.346 & 65.1 \\
$\mathbf{( 5 A}-\mathbf{b})$ & 1.5708 & 1.297 & 74.6 \\
$(\mathbf{5 A}-\mathbf{c})$ & 1.5639 & 1.260 & 63.3 \\
$(\mathbf{5 A}-\mathbf{d})$ & 1.5683 & 1.292 & 40.6 \\
$(\mathbf{5 B}-\mathbf{a})$ & 1.5491 & 1.256 & 61.4 \\
$(\mathbf{5 B}-\mathbf{b})$ & 1.5411 & 1.218 & 60.4 \\
$\mathbf{( 5 B}-\mathbf{c})$ & 1.5365 & 1.190 & 51.0 \\
$\mathbf{( 5 B}-\mathbf{d})$ & 1.5400 & 1.216 & 54.8 \\
$\mathbf{( 5 C}-\mathbf{a})$ & 1.5376 & 1.211 & 72.0 \\
$\mathbf{( 5 C}-\mathbf{b})$ & 1.5325 & 1.183 & 84.9 \\
$\mathbf{( 5 C}-\mathbf{c})$ & 1.5241 & 1.151 & 87.1 \\
$\mathbf{( 5 C}-\mathbf{d})$ & 1.5310 & 1.180 & 73.5 \\
\hline
\end{tabular}

a) refractive index

b) density
Table 2 Inhibition of Tyrosinase and Superoxide Dismutase for $(5 A-a) \sim(5 C-d)$.

\begin{tabular}{|c|c|c|c|}
\hline \multirow{2}{*}{ Compound $^{\text {a) }}$} & \multicolumn{2}{|c|}{ Tyrosinase } & \multirow{2}{*}{$\mathrm{SOD}^{\mathrm{c})}$} \\
\hline & Tyrosine & L - Dopa & \\
\hline$(5 A-a)$ & 10.8 & 5.0 & -7.5 \\
\hline$(5 A-b)$ & 10.4 & 2.0 & -3.2 \\
\hline$(5 \mathrm{~A}-\mathrm{c})$ & 8.3 & -1.5 & 1.2 \\
\hline$(5 \mathrm{~A}-\mathrm{d})$ & -1.8 & 2.0 & 0.1 \\
\hline$(5 B-a)$ & 12.5 & 10.0 & -2.5 \\
\hline$(5 B-b)$ & 19.0 & 20.1 & -1.7 \\
\hline$(5 B-c)$ & 27.4 & 16.8 & 41.6 \\
\hline$(5 B-d)$ & 12.9 & 18.6 & -17.8 \\
\hline$(5 C-a)$ & 42.9 & 35.3 & 2.1 \\
\hline$(5 C-b)$ & 74.2 & 57.2 & 13.2 \\
\hline$(5 C-c)$ & 86.2 & 46.0 & 11.1 \\
\hline$(5 C-d)$ & 27.6 & 30.7 & 9.4 \\
\hline Arbutin & 7.5 & 14.9 & 0.5 \\
\hline Ellagic Acid & -13.6 & 2.0 & -3.7 \\
\hline Kojic Acid & 91.2 & 82.3 & 25.4 \\
\hline
\end{tabular}

a) Concentration; $0.1 \mathrm{mM}$

b) Inhibitory rate $(\%)$

c) Superoxide Dismutase

Table 3 The Effects of Primary Skin Irritation Test of (5C-b).

\begin{tabular}{|c|c|c|c|c|c|c|}
\hline Test body & $1 \mathrm{~h}$ & $24 \mathrm{~h}$ & $48 \mathrm{~h}$ & $72 \mathrm{~h}$ & $\begin{array}{c}\text { Absolute } \\
\text { estimation }\end{array}$ & Irritation level \\
\hline $5.0 \%$ sample+squalane & 0.00 & 0.20 & 0.20 & 0.00 & 0.20 & non-stimulus \\
\hline $1.0 \%$ sample+squalane & 0.00 & 0.20 & 0.00 & 0.00 & 0.20 & non-stimulus \\
\hline $0.1 \%$ sample+squalane & 0.00 & 0.40 & 0.20 & 0.00 & 0.40 & weak-stimulus \\
\hline Squalane only & 0.00 & 0.00 & 0.00 & 0.00 & 0.00 & non-stimulus \\
\hline
\end{tabular}

tion activity and superoxide dismutase to develop whitening agents for cosmetics. (5A-a) $\sim(\mathbf{5 C}-\mathbf{j})$ were tested for a whitening effect in vitro (5) and in vivo (6). The effects of the assay are shown in Tables 2 and 3. The effects of in vitro are shown in Table 2.

We paid special attention to the $(\mathbf{5 C})$ series. $(\mathbf{5 C}-\mathbf{a})$ $(5 \mathrm{C}-\mathrm{j})$ inhibited more strongly than arbutin or ellagic acid. (5C-b) and (5C-c) indicated good inhibition at $74.2 \%$ and $86.2 \%$ of tyrosinase activity with the tyrosine substrate. As inhibitors these two compounds are as strong as kojic acid with tyrosine substrate, and stronger than arbutin or ellagic acid with the L-DOPA substrate. We synthesized (5C-k) and (5C-I) each possessing an estragole derivatives as analogous compounds of $(5 \mathbf{C}-\mathbf{b})$ and $(\mathbf{5 C}-\mathbf{c})$. The difference of $(\mathbf{5 C}-\mathbf{k})$, $(5 \mathrm{C}-\mathrm{l})$ and $(5 \mathrm{C}-\mathrm{b}),(5 \mathrm{C}-\mathrm{c})$ is in their structure regarding the presence of estragole or thioestragole derivatives. (5C-b) and (5C-c) which include a thioestragole derivatives have a higher inhibition of tyrosinase activity than (5C-k) and (5C-l), which includes an estragole derivatives. In the $\mathrm{S}$ atom the influence with the inhibition of tyrosinase activity was determined. We considered the physical property of the C-S and C-O bonds. The bond dissociation energy of C-S is weaker than C-O (7). When the $\mathrm{C}-\mathrm{S}$ bond dissociates, $\mathrm{SH}$ compounds are formed under acidic condition. It is clear that SH compounds do not inhibit the tyrosinase activity but form colorless melanin which is known as pheomelanin by reaction of dopaquinone $(8,9)$. Human skin is a weak acid (10) and cosmetics are desirable weak acids (11). SH compounds formed by dissociation of C-S bonds under weak acid react with dopaquinone, then switch to 
the pathway of pheomelanin.

By increasing the number of methylene groups from the aromatic ring to the thioesteratic site, inhibition of tyrosinase activity increases. The length of the side chain, which includes the thioesteratic site, may thus be a factor of inhibition of tyrosinase activity. In the primary irritation test, a concentration of $0.1 \%$ was a weak stimulus and as for other concentrations, the response toward the skin was small (Table 3). So, we judged that there is no problem with the primary irritation test.

\section{References}

1. Imokawa, G., Kawai, M., Mishima, Y. \& Motegi, I. (1986) Arch. Dermatol. Res., 278, 352-362.

2. Takahashi, M. (2000) Development of advanced cosmetics,
213-223.

3. Nomura, M., Nishimura, K., Fujihara, Y., Tada, T., Hattori, F. \& Shimomura, K. (2000) J. Jpn Oil Chem. Soc. (J. Oleo Sci.), 49, 143-149.

4. Nomura, M., Sakakiyama, T. \& Fujihara, Y. (1997) Nippon Kagaku Kaishi (in Japanese), 1997, 46-52.

5. Tada, T., Nomura, M., Shimomura, K. \& Fujihara, Y, (1996) Biosci. Biotech. Biochem., 60, 1421-1424.

6. Draize, J. H., Woodard, G. \& Cavery, H. O. (1944) J. Pharmacol Exp. Ther., 82, 377-390.

7. Ohae, S. (1982) Yuuki iou kagaku (Hannou kikou hen), Kagakudoujin, Tokyo, pp. 2-8.

8. Prota, G. \& Thomason, R. H. (1976) Endeavour, 35, 32-38.

9. Prota, G. (1980) J. Invest. Dermatol., 75, 122-127.

10. Draize, J. H. (1942) J. Invest. Dermat., 5, 77-85.

11. Marcus, F., Colaizzi, J, L. \& Barry, H. (1970) J. Pharm. Sci., 59, 1616-1620. 